\title{
ECOLINGUISTIC ASPECT OF COOPERATION: COMPARATIVE PERSPECTIVE
}

\section{Artur Ivanov $^{1}$}

DOI: https://doi.org/10.30525/978-9934-26-002-5-14

A distinctive feature of modern scientific paradigm is that new adjacent areas appear at the intersection of various fields of science, which often have completely different objects and subjects of research, as well as methods. Such phenomena are of great interest to the researchers these days, and linguistics is no exception to the rule. A new form of lingustic studies named ecolinguistics came to life and began to develop thanks to the symbiosis of different scientific branches in the second half of the 20th century. As a result, the conceptual apparatus of linguistics was replenished with such terms as westernization, vulgarization, etiquette insufficiency, stylistic imbalance, linguistic fashion, etc [1, p. 15; 9, p. 12].

Einar Haugen, an American linguist, was the first to have stated the relevance of considering a language from the standpoint of its harmonious and balanced co-existence with nature [2, p. 65]. Applying the basic ideas of biology and ecology, E. Haugen argues that language ecology studies the relationship between language and its environment. By environment he understands a certain society that uses one or more linguistic codes. The social nature of this phenomenon is emphasized along with the physiological one, as any language exists in a speaker's mind and can function only in interaction with other communicants.

It has to be underlined that the ecology of language, or linguoecology, and ecolinguistics are viewed upon as two distinct approaches. Nonetheless there is a certain overlap between them. This concept was first reflected in M.A. Halliday's works [3, p. 98]. According to him, the object of linguoecology is language and its disappearing forms, while ecolinguistics is focused on the study of natural languages in their natural environment. The former approach is concerned with seeking ways of preserving languages, whereas the latter considers social and natural factors of language functioning. At the same time, both approaches hypothesize the existence of a linguo-geobiocenosis, or harmonious coexistence of language speakers and their environment.

In this regard, the definition of ecolinguistics proposed by A. P. Skovorodnikov seems to be consistent and practical. He interprets ecolinguistics as «the study of language problems and speech degradation (the

\footnotetext{
${ }^{1}$ Minsk State Linguistic University, Republic of Belarus
} 
study of factors that negatively affect the development of language and its speech implementation)» [4, p. 72]. This branch of general linguistics also studies language rehabilitation, i.e. «ways and means of enriching a language and improving the system of ethical and pragmatic principles)» [4, p. 72].

At the moment, there are three aspects of analyzing the ecology of language, namely interlingual, translingual and intralingual. Within the framework of interlingual approach, multilingualism as a habitat of various ethnic languages is investigated, as well as the problem of language disappearance and, as a consequence, reduction of linguistic diversity. The translingual aspect is mainly associated with the use of units within one language belonging to a particular culture in the context of another language and, therefore, another culture. This approach is primarily reflected in environmental stylistics, ecology of translation and intercultural communication. Special attention should be paid to the intralingual aspect of ecolinguistics, which borders on speech culture, stylistics and rhetoric and also includes norm violation studies, as well as clarity, consistency, expressiveness and other communicative properties of speech [5, p. 78].

Following the logic of the latter approach, it seems obvious that ecolinguistics is connected with observing pragmatics principles. Among these we can find such well-known concepts as G. P. Grice's principle of cooperation [6, p. 45], J. Leach's principle of politeness [7, p. 20], P. Brown and St. Levinson's concept of positive and negative faces [8, p. 23]. Cooperativity is known to have a direct correlation with the above-mentioned principles, for they become a hallmark of this type of communication as opposed to confrontation, in which violating these principles can be observed. In this regard, it is necessary to consider two related categories - ecological/non-ecological and cooperative/non-cooperative nature of discourse.

According to some researchers, the main parameters of eco-friendly communication include politeness, benevolence, tolerance, the interlocutors' desire to create a common positive emotional center, while the criteria for non-ecological communication are intolerance, emotional inconsistency, inadequate tone of communication, negative assessment, linguistic norm violation [9, p. 13].

This proves that language eco-friendliness is closely related to cooperation, but the latter is more focused on intentionality and strategic nature of communication. Cooperation also takes into account the fact that all interlocutors should achieve their goals by optimal, mutually acceptable means, whereas ecolinguistics mainly pivots on other discourse characteristics, primarily connected with the process. The overlap between environmental and cooperative research is presented below. 


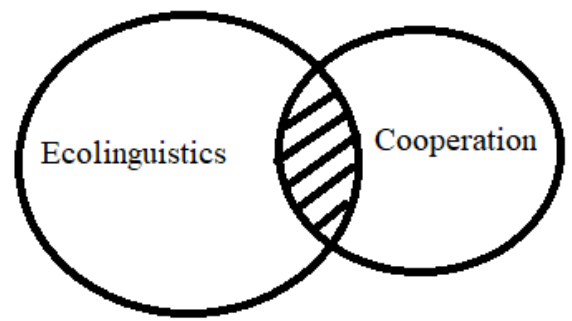

Figure. Interaction of ecolinguistics and cooperation studies

It has to be mentioned that both language eco-friendliness and cooperation can be culturally specific, and therefore, reflect certain differences that stem from a particular culture. For example, westernization of the Russian language, i.e. numerous borrowings from English and other European languages, is studied within the framework of ecolinguistics, while for the English language itself this issue has no relevance altogether. At the same time, depending on the communicative situation and the purposes of interaction, excessive use of loan words can be viewed upon as either cooperative or non-cooperative. Compliment tactics can often exemplify cooperation, for they are used to enhance an interlocutor's status in both British and American cultures, but in Russian-speaking culture compliment is used less actively because communicants will deem it insincere and take it as a sign of hidden agenda. Compliment does not affect either ecological or nonecological nature of discourse though.

Thus, cooperation can be researched within the framework of ecolinguistics, being a criterion for distinguishing between ecological or non-ecological communication. Nevertheless, ecolinguistics has wider semantics, and cooperation studies cannot be fully absorbed into it, as cooperation itself has certain distinctive features (i.e. intentional and strategic nature). The category of eco-friendly discourse, as well as the category of cooperation, obviously depend on a language society and, thus, can transform and modify, forming different behavioral patterns. Both eco-friendliness and cooperation are integral language components that are essential for achieving effective communication.

\section{References:}

1. Stibbe, A. (2015). Ecolinguistics : language, ecology and the stories we live by. NY: Abingdon, Oxon; Routledge, $210 \mathrm{p}$.

2. Haugen, E. (1972). The Ecology of Language. Stanford: Stanford University Press, $366 \mathrm{p}$.

3. Halliday, M. A. K. (2003) On Language and Linguistics. Vol. 3. London: Continuum, $490 \mathrm{p}$. 
4. Skovorodnikov, A. P. (2000). K stanovleniju sistemy lingvoekologicheskoj terminologii [On the genesis of the system of ecolinguistic terminology]. Spetsializirovannyj Vestnik Krasnoyarskogo gos. un-ta [Specialized herald of Krasnoyarsk state university]. Krasnoyarsk, pp 70-78. (in Russian)

5. Belozerova, N. N., Labunets, N. V. (2012). Ecolingvistika: v poiskah metodov issledovaniya [Ecolinguisrics: seeking for methods of research]. Tyumen: Tyumen University Press, 256 p. (in Russian)

6. Grice, H. P. (1975). Logic and Conversation. In P. Cole, \& J. L. Morgan. (Eds.), Syntax and Semantics, Vol. 3, Speech Acts (pp. 41-58). New York: Academic Press.

7. Leech, G. N. (1983). Principles of pragmatics. New York: Longman Group Limited, $250 \mathrm{p}$.

8. Brown, P., Levinson, St. (1987). Politeness: some universals in language usage. Cambridge: Cambridge University Press, 345 p.

9. Solodovnikova, N. G. (2010). Ekologichnost' emotivnoy kommunikatsii (na materiale predvybornyh kreolizovannyh gazetnayh tekstov) [Eco-friendliness of emotive communication (as exemplified in pre-election creolized newspaper texts)] (PhD Thesis), Volgograd: Volgograd State Pedagogical University.

\section{THE PROBLEM OF LIFE AND DEATH IN L.ULITSKAYA'S NOVEL «DANIEL STEIN, INTERPRETER»}

\section{Yuliia Kovryha ${ }^{1}$}

DOI: https://doi.org/10.30525/978-9934-26-002-5-15

The novel «Daniel Stein, interpreter» is, of course, a story about a human life full of happiness and sorrows, love and hate, forgiveness and resentment. This is a novel about quite difficult period in the life of Soviet society associated with the events of World war II, being in the ghetto, executions, and concentration camps. In addition to the political hardships of life, the characters face other problems related to life in an orphanage and the consequences of this, misunderstandings between children and parents, payment for sins, etc. Concerning the problem of «fathers and children», L. Ulitskaya shows that blood ties are not the key to a good relationship. There are often insults, misunderstandings, and even hatred between relatives who are presented as novel characters. Giving characters' «confessional» letters, the writer represents the idea that a good relationship is a daily work; it takes a lot of effort to understand the other, forgive and love.

\footnotetext{
${ }^{1}$ Kharkiv National Agrarian University named after V. V. Dokuchaiev, Ukraine
} 